\title{
LIFETIME EARNINGS, SOCIAL SECURITY BENEFITS, AND THE ADEQUACY OF RETIREMENT WEALTH ACCUMULATION
}

\author{
Eric M. Engen* \\ William G. Gale \\ Cori Uccello \\ CRR WP 2004-10 \\ Released: April 2004 \\ Draft Submitted: March 2004 \\ Center for Retirement Research at Boston College \\ 550 Fulton Hall \\ 140 Commonwealth Ave. \\ Chestnut Hill, MA 02467 \\ Tel: 617-552-1762 Fax: 617-552-1750 \\ http://www.bc.edu/crr
}

\begin{abstract}
* Eric M. Engen is a residential scholar at the American Enterprise Institute. William G. Gale is The Arjay and Frances Fearing Miller Chair and a Senior Fellow in Economic Studies at The Brookings Institution. Cori Uccello is a consultant for the Urban Institute. The research reported herein was performed pursuant to a grant from the U.S. Social Security Administration (SSA) to the Center for Retirement Research at Boston College (CRR). The opinions and conclusions are solely those of the authors and should not be construed as representing the opinions or policy of the SSA or any agency of the Federal Government or of the CRR. The authors would like to thank Brennan Kelly, Ben Harris, Samara Potter, and Emily Tang for research assistance and owe special thanks to Karl Scholz for providing data on lifetime earnings.
\end{abstract}

(C) 2004, by Eric M. Engen, William G. Gale, and Cori Uccello. All rights reserved. Short sections of text, not to exceed two paragraphs, may be quoted without explicit permission provided that full credit, including (C) notice, is given to the source. 


\section{About the Center for Retirement Research}

The Center for Retirement Research at Boston College, part of a consortium that includes parallel centers at the University of Michigan and the National Bureau of Economic Research, was established in 1998 through a grant from the Social Security Administration. The goals of the Center are to promote research on retirement issues, to transmit new findings to the policy community and the public, to help train new scholars, and to broaden access to valuable data sources. Through these initiatives, the Center hopes to forge a strong link between the academic and policy communities around an issue of critical importance to the nation's future.

\section{Center for Retirement Research at Boston College}

550 Fulton Hall

140 Commonwealth Ave.

Chestnut Hill, MA 02467

phone: 617-552-1762 fax: 617-552-1750

e-mail: crr@bc.edu

http://www.bc.edu/crr

Affiliated Institutions:

American Enterprise Institute

The Brookings Institution

Massachusetts Institute of Technology

Syracuse University

Urban Institute 


\begin{abstract}
This paper provides new evidence on the adequacy of household retirement saving. We depart from much previous research on the adequacy of saving in two key ways. First, our underlying simulation model of optimal wealth accumulation allows for precautionary saving against uncertain future earnings. Second, we employ data on lifetime earnings. Using data from the 1992 Health and Retirement Study, we find that households at the median of the empirical wealth-lifetime earnings distribution are saving as much or more as the underlying model suggests is optimal, and households at the high end of the wealth distribution are saving significantly more than the model indicates. But we also find significant undersaving among the lowest 25 percent of the population. We show that reductions in social security benefits could have significant deleterious effects on the adequacy of saving, especially among low-income households. We also show that, controlling for lifetime earnings, households with high current earnings tend to save far more adequately than other households.
\end{abstract}




\section{Lifetime Earnings, Social Security Benefits, and the Adequacy of Retirement Wealth Accumulation}

The United States has traditionally depended on the so-called three-legged stool -- Social Security, private pensions, and additional personal saving -- to finance retirement, but all three legs are becoming increasingly creaky. Social security and Medicare face financial long-term shortfalls, due to a combination of the imminent retirement of the baby boom generation, lengthening lifespans generally, and projections of rising per-capita health care expenditures. The trend in pensions from defined benefit to defined contribution plans brings with it a set of opportunities but also a set of risks for future retirees. Official aggregate saving rates have been extremely low in recent years, and evidence shows that some households save very little, especially in the form of financial assets.

The extent to which households are already saving adequately for retirement is thus an important issue for policy makers, especially as they deal with issues like social security reform. It is also a central issue in academic research that aims to understand the fundamental forces that shape the way people make saving and forward-looking decisions.

Despite the importance of the question, there is still widespread controversy on how well households are preparing for retirement. Researchers have taken a wide variety of approaches to examine the adequacy of households' saving for retirement. These include measuring changes in household consumption at the time of retirement, calculating the annuitized value of existing wealth, comparing the wealth accumulation patterns of current and previous generations, and comparing the results of simulation models of optimal wealth accumulation to households' actual 
saving behavior. Each approach generates useful information, but each also has shortcomings that may limit the applicability of the results. ${ }^{1}$

This paper provides new evidence on the adequacy of household wealth accumulation. Our research departs from most previous analyses in two key ways. First, whereas most simulation models of optimal wealth accumulation assume that earnings are non-stochastic, we follow our own earlier work (Engen, Gale, and Uccello 1999) in deriving optimal wealth accumulation patterns for households in a stochastic life-cycle model that allows for uncertainty in earnings and mortality. Uncertainty about future earnings implies that there will be a distribution of optimal wealth-earnings ratios, rather than a single benchmark ratio, among households that are otherwise observationally equivalent (that is, have the same age, education, pension status, marital status, and wage history). This finding fundamentally changes the interpretation of observed saving patterns relative to a non-stochastic model. In particular, it implies that some households should be expected to exhibit low ratios of wealth to lifetime earnings even if every households is forward-looking and making optimal choices.

The second way in which we depart from most previous research is to base our measures of adequate wealth accumulation on lifetime earnings rather than current earnings. ${ }^{2}$ There are several reasons to believe that using data on lifetime earnings will prove useful in studying the adequacy of saving. Most importantly, lifetime earnings are almost certainly more closely correlated with economic well-being during working years and desired economic status in retirement than are earnings in any particular year. In addition, use of lifetime earnings may help

\footnotetext{
${ }^{1}$ A complete review of the literature is beyond the scope of this paper. Engen, Gale, Uccello (1999) and Congressional Budget Office (2003) provide recent reviews of the literature.

${ }^{2}$ Gustman and Steinmeier (1998) and Scholz, Seshadri and Khitatrakun (2003) also use lifetime earnings data to study the adequacy of saving.
} 
clarify who is saving too little. For example, Mitchell, Moore and Phillips (1998) and Engen, Gale, Uccello (1999) find that, controlling for other factors, households with higher current earnings appear to be less likely to be saving adequately for retirement, where adequate saving is defined as having a sufficiently high ratio of wealth to current earnings. In contrast, Dynan, Skinner, and Zeldes (2000) find that high-earning households save a greater share of their income. A possible explanation of this apparent difference is that people with high current earnings are more likely to have current earnings that exceed average lifetime earnings. Hence, if their wealth targets are actually developed with respect to lifetime earnings, their adequacy of saving will be systematically understated by examining the ratio of wealth to current earnings. Likewise, the adequacy of saving by people who have temporarily low earnings would be overstated by a measure that looks at the ratio of wealth to current earnings.

Our results suggest that households at the median of the wealth-lifetime earnings distribution are saving as much as, or more than, the underlying model suggests is optimal, and households at the high end of the wealth distribution are saving significantly more than the model indicates. But we also find significant undersaving among the lowest 25 percent of the population. This is consistent with the results in Engen, Gale, and Uccello (1999), which uses data on current earnings.

The central role of Social Security in the income of many elderly households highlights the potential impact of policy reforms on the adequacy of saving. We find that a 30 percent cut in social security benefits would have significant effects on the level and distribution of the adequacy of saving. The overall share of households whose actual wealth exceeded the median optimal target wealth-earnings ratio would fall by 5 percentage points, or 10 percent. The drop would be much higher among lower-income households and among households with less 
education than other households.

The overall effect of a 30 percent social security benefit reduction is several times as large as the effects of a 40 percent reduction in stock market values. Other changes, such as increases in health expenditures or improvements in life expectancy, also have significant effects on the adequacy of saving.

Lastly, we compare analysis using ratios of wealth to current earnings and those using ratios of wealth to lifetime earnings. Controlling for lifetime earnings, households with current earnings tend to save far more adequately than other households.

Section I discusses our definition of adequate saving. Section II describes the underlying model. Section III discusses the data. Section IV presents the basic results. Section V examines the effects of social security reform on the adequacy of saving. Section VI provides sensitivity analysis. Section VII compares the results using wealth-lifetime earnings ratios to wealthcurrent earnings ratios. Section VIII offers caveats and conclusions.

\section{Defining Adequate Saving}

We define a household to be saving adequately if it is accumulating enough wealth to be able to smooth its marginal utility of consumption over time in accordance with the optimizing model of consumption described in the next section. Other possible definitions relate to poverty rates among the elderly, the maintenance of pre-retirement living standards in retirement, economy-wide golden-rule levels of capital accumulation and so on.

Our definition is the natural one for examining the adequacy of saving from the perspective of economic research, and takes seriously the concern that people may not be behaving optimally. We simulate optimal behavior with the model and then compare the model 
results with actual wealth accumulation patterns. Thus, whereas in most other contexts deviations between a model and the data indicate that the model is flawed, we will interpret any shortfall of actual wealth relative to the model's wealth patterns as evidence that behavior is flawed, that is, that actual saving is too low. This assessment, of course, is subject to many qualifications about features of the model that do not accurately capture the full set of incentives and opportunities facing households.

Our results, however, will speak only to whether the observed levels of wealth are consistent with the patterns of an optimizing model. They cannot in any way prove that people are actually solving the optimization problem defined in the simulation model. Nor do the results speak to several important related issues, such as whether social security or pensions are responsible for observed levels of wealth accumulation, or whether higher saving would raise households' or national welfare.

\section{Modeling Adequate Saving}

This section highlights key aspects of the model used to develop benchmark saving patterns. Engen, Gale, and Uccello (1999) provide a complete description and citations to related literature.

\section{A. Description}

Households enter the model with two adults aged 21. One child is added at age 25 and a second at age 28. Each child leaves the home at age 21. Families are not linked across generations. Each adult faces an age-varying probability of dying, with a maximum life span of 110 years. Each year, the assets of those who die are bequeathed to members of the generation that is then 45 years old. The bequests are distributed in accordance with the wealth distribution 
of the 45-year-olds, thus capturing the empirically established tendency of wealthier households to receive larger inheritances. The inheritance is assumed to be unanticipated.

In each period, forward-looking households maximize expected lifetime utility by choosing total consumption (consumption per capita times the number of people in the household) and total saving subject to a lifetime budget constraint, nonnegativity constraints on net assets, income and payroll taxes, and uncertainty regarding future earnings, life span, and inheritances. There are no markets for insurance against these uncertainties. Because there is a positive probability of death at each age, borrowing against the uncertain portion of future income and inheritances is not permitted.

Utility is separable over time, and separable within a time period between consumption and leisure. The utility function for consumption exhibits constant relative risk aversion, a constant intertemporal elasticity of substitution, and constant prudence, which implies that risky income and uncertain life spans lead to precautionary saving. Thus, households save for retirement and as a precaution against downturns in future income and the possibility of outliving assets once retired.

Before retirement, consumption may be financed by labor earnings, decumulations of previously accumulated assets, or inheritances received. After retirement, consumption is financed by assets accumulated earlier, which are fully taxable, and by annuity income from social security and private DB pensions. Labor supply is exogenous and retirement occurs at a predetermined age. Household earnings are modeled as the sum of a stochastic component and a non-stochastic component. The latter follows a hump-shaped pattern with respect to age and varies by education class. 
Because the model does not have a closed-form solution, and the analytical solution would be intractable, we use a numerical solution method to solve households' consumptionsaving problem. Earnings shocks over the life cycle are simulated with a random number generator for each of 10,000 households. Because households receive different earnings shocks, they end up with different realized income, consumption, saving, and wealth.

The model requires specification of numerous parameter values. We highlight the most important specification issues here. The conditional survival probabilities for males and females are based on estimates from the life tables for 1994 used by the Social Security Administration (1997). Retirement occurs at age 62.

Because saving is the difference between income (which before retirement consists largely of labor earnings) and consumption, the specification of the age-earnings profile is an important determinant of optimal saving patterns. To estimate the mean age-earnings profile, we use panel data on earnings of employed heads of households and their spouses from the Panel Survey of Income Dynamics, conducted by the University of Michigan's Institute for Social Research, from 1980 to 1992. We exclude the self-employed and households where the head is over 65 years old. We estimate a fixed-effects model with log earnings as a function of age, age squared, and year dummies to control for macroeconomic effects, with separate equations for household heads with 16 or more years of education and those with less education. Earnings for the group with more education are always higher, rise and fall more steeply, and peak at later ages than for the group with less education. In addition, the wages of all age groups are assumed to rise by 1 percent per year to reflect aggregate growth in the economy.

To measure the variability in current earnings, we use data from the Internal Revenue Service-Michigan tax panel to estimate the stochastic process for the logarithm of earnings 
variations (Engen 1993a, 1993b). Measurement error is less of a problem with earnings data collected from Internal Revenue Service W-2 forms filed with income tax returns, because wages are directly reported by employers. Based on that analysis, we model the stochastic process for labor earnings shocks as a first-order autoregressive process with a persistence parameter of 0.85 and a variance of 0.05 . Under this specification, about half of a given shock to earnings remains after five years.

We impose a progressive income tax structure, similar to the actual U.S. system in 1998, with statutory marginal rates of 15 percent, 28 percent, 31 percent, 36 percent, and 39.6 percent. The taxable income brackets, in dollars, are those effective in 1998 for joint tax filers. Households are allowed a standard deduction of $\$ 7,100$ and an exemption of $\$ 2,650$ for each person. To capture the effect of preferential capital gains tax rates and tax-preferred saving vehicles, without introducing the substantial complication of explicitly modeling tax-favored saving, tax rates on capital income are capped at 20 percent. The social security payroll tax is modeled by taxing labor earnings up to a limit of $\$ 68,400$ at a 6.2 percent rate- the employee share of the payroll tax.

The interest rate has two roles in the model: it affects the growth of consumption and the overall return on saving. We specify the interest rate as an average of the historical real risk-free rate of return and a mix of all returns, and thus use an after-tax real rate of return of 3 percent (the average tax rate on capital income is used here). ${ }^{3}$ We set the coefficient of relative risk aversion at 3 , which implies an intertemporal elasticity of substitution of 0.33 .

\footnotetext{
${ }^{3}$ If the model had a safe asset and risky assets, the Euler equation for optimal consumption growth would be determined by the return on the safe asset, and the overall return on saving would be a weighted average of these assets. The real return on short-term Treasury bills has averaged about 1 percent historically. Longer-term government and corporate bonds have yielded about 2 percent in real terms, and the equity market about 9 percent in the postwar period. A market-weighted basket of these returns gives a real pre-tax return of about 5 percent.
} 
The model assumes that each household receives social security based on features of the average age-earnings profile of its education class, not on its individual wage profile. For example, among households without a defined benefit pension, social security is assumed to replace 35 percent of average final earnings for those with less than sixteen years of education, and 21 percent of average final earnings for those with sixteen years or more of education.

Specifying the appropriate time preference rate is difficult but crucial. The goal of the model is to describe optimal (and, implicitly, time-consistent) behavior, rather than actual behavior. As a result, choosing the rate so that the model is well calibrated with household wealth data, or using estimates of time preference rates from previous empirical studies, would inappropriately impose the assumption that households' actual behavior was optimal. Basing the choice on time preference rates used in other simulation models would also be misleading, since most of these models aim to explain actual behavior. We use the after-tax rate of interest (3 percent) as our base case, and in some cases, use zero as an alternative.

\section{B. Optimal Saving Behavior}

We report results in terms of the ratio of current wealth to lifetime earnings to date. ${ }^{4}$ The wealth measure excludes the present value of social security and defined benefit pensions.

Optimal wealth-earnings ratios will evolve differently for different households for two reasons. The first is that differences in education affect the level and shape of the age-earnings profile and differences in pension coverage affect retirement income. Table 1 reports median optimal wealth-lifetime earnings ratios (which we will refer to as wealth-earnings ratios) for

\footnotetext{
${ }^{4}$ Despite our reporting the results this way, our model should not be confused with a "buffer stock" or target saving model (see Carroll, 1992). In our model, as already noted, households save both for retirement and as a precaution against uncertain income and life span. The model generates consumption-age profiles that rise, peak in the mid$50 \mathrm{~s}$, and then decline, controlling for family size. Because of the need for precautionary saving, generated by uncertain earnings, the general shape of the consumption-age profile is invariant with respect to whether the time preference rate is above or below the after-tax rate of return.
} 
households classified by age, education, and pension status, assuming a time preference rate of 3 percent. Optimal wealth-earnings ratios rise over the life cycle. When education status is controlled for, households with pensions have lower optimal wealth-earnings ratios than those without, because pensions provide retirement income. When pension status is controlled for, college graduates have lower optimal wealth-earnings ratios when young and almost equal or higher ratios when old than do other households.

The second reason why wealth-earnings ratios vary across households is distinct to our methodology: households receive different earnings shocks over time and at a given point in time. As a result, households that are observationally equivalent in the data-that is, that are identical with respect to age, lifetime earnings, family size, life expectancy, education, and pension status-will have different optimal wealth-earnings ratios. Table 2 shows the importance of heterogeneous earnings shocks in generating a distribution of wealth-earnings ratios. The table focuses on college graduates with pensions, but similar results occur for other groups. With a time preference rate of 3 percent, wealth-earnings ratios among 35 to 39 year olds vary by a factor of 190 , from 0.0004 at the 5 th percentile to .0765 at the 95 th percentile. Among 60 to 62 year olds, wealth-earnings ratios vary by a factor of 16 .

These observed ratios represent households' optimal responses to the pattern of earnings shocks they receive. The low wealth accumulation exhibited by a significant minority of households in the simulation model is consistent with optimizing behavior and in no way implies a retirement saving shortfall owing to myopia, irrationality, or poor information. Similar dispersion occurs with a time preference rate of zero, though all of the benchmarks are higher. 


\section{Data Issues}

We use data from the 1992 Health and Retirement Survey (HRS), conducted by the Institute for Social Research at the University of Michigan. In 1992 the survey gathered data on a nationally representative sample of persons born in 1931 to 1941 and on their spouses regardless of age. Reinterviews have occurred every two years since then. The survey oversamples blacks, Hispanics, and Florida residents and contains detailed information on wealth, pensions, income, employment, demographics, and health. Our HRS sample consists of the 2,626 married households where the husband was born between 1931 and 1941 and worked at least twenty hours per week in the 1992 survey. Our results are weighted in accordance with a nationally representative population. It is worth keeping in mind that for, some of the subgroups, the sample sizes are small.

We use lifetime earnings data from Khitatrakun, Kitamura and Scholz (2000). They develop a lifetime earnings history for each individual in their HRS sample using data on reported lifetime earnings to date and matched Social security records, and imputing missing information from regression analysis. They estimate separate wage profiles for different demographic groups. They aggregate the results across spouses to form household measures of lifetime earnings to date. We use the measure of the lifetime earnings to date as the denominator of our wealth-earnings ratios.

Because the simulation model accounts for both precautionary saving and saving for retirement, our empirical wealth measure needs to be broad enough to account for both. We define three measures of wealth. We define broad wealth as all net worth other than equity in vehicles. Specifically, broad wealth is the sum of equity in the primary residence, other real estate equity, equity in businesses, and net financial assets. Financial assets include balances in 
DC plans, 401(k) plans, Individual Retirement Accounts, and Keogh plans as well as non-taxadvantaged financial assets, less consumer debt. Narrow wealth is broad wealth less all equity in the primary residence. Intermediate wealth is broad wealth less half of equity in the primary residence.

For reasons explained in Engen, Gale, and Uccello (1999), we believe it is appropriate to include housing equity in retirement saving calculations. Nevertheless, it may not be appropriate to include every dollar of equity, since liquidating housing wealth through sale or reverse mortgages imposes some transactions costs. Excluding half of housing wealth—as we do with our intermediate wealth measure - to account for transactions costs certainly overestimates such costs. Therefore, we believe that our intermediate wealth measures generate the reasonable and probably conservative empirical results. Nevertheless, we present many of the results for all three wealth measures, which together bound all the possible effects of including housing equity.

All of the simulated wealth measures above exclude social security. In the HRS data, however, estimates of expected DB pension benefits can be generated. We use the additional information provided by the DB pension wealth data in the HRS and therefore include DB pension wealth in the empirical wealth measures. ${ }^{5}$ Thus, unlike in the simulation model, pension wealth varies across households that have pensions, even after controlling for education status. Because we include DB pensions in wealth, we compare the resulting wealth measures from the HRS data with the simulation's wealth benchmarks above for households that do not have pension coverage. We do this to avoid double counting DB pension assets.

Focusing the sample on married couples where the husband is still a full-time worker may somewhat bias the sample over time, since wealthier households may retire earlier. As

\footnotetext{
${ }^{5}$ This approach follows that of Moore and Mitchell (1997) and Gustman and Steinmeier (1998).
} 
reported in Engen, Gale, and Uccello (1999), this may affect the observations for 61- and 62-year olds, but is less likely to have a significant effect on younger age groups.

\section{Results}

For a household with a given set of observable characteristics, the simulation model generates a distribution of optimal wealth-earnings ratios, rather than a single optimal level. This implies that we cannot determine precisely the optimal wealth-earnings ratio for any particular household. Instead, we compare the distributions of observed and simulated wealth-earnings data for married households with a given set of characteristics: age, lifetime earnings, education, and pension status. Thus, our strategy for examining the adequacy of saving focuses mainly on two issues: determining the proportion of households whose wealth-earnings ratios exceed the median simulated wealth-earnings ratio for households with the same characteristics; and comparing wealth-earnings ratios at different percentiles of the actual and simulated distributions. Both approaches provide valuable information, but neither permits us to identify which particular households are saving adequately or inadequately. ${ }^{6}$

\section{A. Median Wealth-Earnings Ratios}

Table 3 reports the results of comparing each HRS household's wealth-earnings ratio with the median of the distribution of wealth-earnings ratios from the simulation for households with the same characteristics, assuming a 3 percent time preference rate. For the full sample, the table shows that 56 percent of households have ratios of intermediate wealth to lifetime earnings to date (which we will refer to as "wealth-earnings" ratios) that exceed the median simulated wealth-earnings ratio for households with the same observable characteristics.

\footnotetext{
${ }^{6}$ As discussed below, recent work by Scholz, Seshadri and Khitatrakun (2003) estimates optimal wealth measures on an individual basis.
} 
The interpretation of this result depends on the fact that the saving benchmark is derived from a stochastic rather than a nonstochastic model. In a nonstochastic model, all households of the same age, earnings patterns, education, and pension status would be assigned the same optimal wealth-earnings ratio, and the finding above would be interpreted as showing that 56 percent of households exceed the optimal ratio. That would mean that 44 percent of households fall short of their assigned optimal wealth-earnings ratio. This would (perhaps erroneously) suggest that a significant portion of the population is undersaving.

In contrast, once it is recognized that households face uncertainty about their future earnings, it is appropriate to use a stochastic model as the benchmark. This in turn implies that one would expect only 50 percent of households to exceed the median wealth-earnings ratio. Thus, the same fact — that 56 percent of actual households exceed the simulated median—would instead suggest adequate, indeed somewhat more than adequate, amounts of wealth accumulation relative to the benchmark at the median of the distribution.

Table 3 also shows that the treatment of housing wealth can have significant effects on the results, with between 47 percent and 65 percent of households having wealth-earnings ratios that exceed the median simulated ratio falls. We emphasize that all of these results should be compared against a benchmark expectation that only 50 percent of households will exceed the median.

The table shows several other interesting results as well. Controlling for education, having a pension is associated with an increase of about 10-19 percentage points in the proportion of households that exceed the median target wealth-earnings ratio. When pensions are controlled for, having more education is associated with an increase of 9-19 percentage points in the likelihood of exceeding the simulated median wealth-earnings ratio. These qualitative results are 
consistent with those of numerous previous studies. ${ }^{7}$ As with previous studies of the adequacy of saving, we do not determine whether the results are due to the direct effects of pensions and education or to unobserved characteristics that affect household saving and are correlated with pension coverage and education.

The results do not vary significantly with respect to age. The proportion of households whose wealth-earnings ratios exceed the median simulated ratio rises as both current and lifetime income rise. This suggests that high-earnings households may have some important difference in tastes or opportunities for saving compared with others. ${ }^{8}$

\section{B. Distribution of Wealth-Earnings Ratios}

Table 4 provides evidence on the distribution of wealth-earnings ratios. The top panel reports data from the HRS using the intermediate wealth measure. The bottom panel provides simulated wealth-earnings ratios from the model, using the same distribution of households across education groups as is found in the HRS.

The median wealth-earnings ratios in the data exceeds the median in the simulation. In addition, the model underestimates wealth-earnings ratios at the high end of the distribution. That is, there is a significant amount of real-world wealth accumulation that the model does not include. This may not be particularly surprising because the model does not include bequest motives or the possibility of receiving a very high rate of return, perhaps on an entrepreneurial investment.

\footnotetext{
${ }^{7}$ See Banks, Blundell, and Tanner (1998); Bernheim (1992); Bernheim and Scholz (1993); Gale (1997); Kotlikoff, Spivak, and Summers (1982); Mitchell, Moore, and Phillips (1998); Moore and Mitchell (1997); Robb and Burbidge (1989); Warshawsky and Ameriks (1998).

${ }^{8}$ For further evidence on these issues see Carroll (2000); Dynan, Skinner, and Zeldes (1996); Gentry and Hubbard (1998).
} 
At the 25th percentile and lower, however, the empirical wealth-earnings ratio is below that of the simulated distribution and the difference is especially large at the 5th percentile. This is consistent with a significant amount of undersaving at the low end of the wealth distribution. It is also consistent, however, with other explanations that the model does not take into account. In particular, the model omits any sort of government-provided consumption floor (Hubbard, Skinner, Zeldes 1995, Scholz, Seshadri, Khitatrakun 2003).

\section{Characteristics of High-Savers}

Table 5 shows the characteristics of "high savers" and "low savers." We define high savers as households whose intermediate wealth-earnings ratios exceed the median ratio from the simulation, and low savers as those below the median. ${ }^{9}$ Before examining these characteristics, it is worth emphasizing that these designations may be misleading. Because the optimal wealth-earnings ratio varies among observationally equivalent households, there is no way to determine, with the current data, whether any particular household is actually saving more than it needs for retirement. It could be that, given its earnings history, the household has an optimal wealth-earnings ratio that is higher than its actual ratio, even though its actual ratio exceeds the median ratio for households with its characteristics. Nevertheless, the typical determinants of households above and below the median target are of interest.

Table 5 shows that the typical high-saver household has more wealth and higher lifetime wages than the typical low saver. High savers have fewer children living at home; they are more likely to be self-employed, to be college graduates, and to have pension coverage; and they are less likely to be nonwhite or Hispanic. High savers are also less likely to smoke and more likely to say they have thought about retirement and they have slightly longer financial horizons. They

\footnotetext{
${ }^{9}$ Similar qualitative patterns emerge if we use definitions of high savers based on broad or narrow wealth and/or the simulation model with a time preference rate of zero.
} 
are more likely to believe they will live to age seventy-five, and they expect to retire earlier than low savers. High savers are more likely to have received an inheritance and, among recipients, have received larger inheritances than low savers.

Table 6 presents estimates of three probit models of whether a household is a high saver. In all of the models, education, pension coverage, and self-employment are associated with a higher likelihood of having an actual wealth-earnings ratio that exceeds the simulated median wealth-earnings ratio for households with the same characteristics. Nonwhite households have lower likelihood of exceeding the medians, controlling for other factors.

Model 1 controls for lifetime earnings levels and basic household demographic variables and the level of lifetime earnings. In this framework, having higher lifetime earnings leads to very strong positive effects on the adequacy of saving. Households with lifetime earnings in excess of $\$ 1.5$ million (1992 dollars) are about 12-16 percentage points more likely to exceed the applicable median target than are households with lifetime earnings below \$1 million.

Model 2, however, shows that the effect of lifetime earnings disappears once current earnings are included. Households with high current income are more likely than others to exceed their median target ratio of wealth to lifetime earnings than other groups. This is consistent with the view that higher current earners save alot and the view that higher current earners have a substantial transitory income, which pushes their current income above their average lifetime earnings. This shows that once lifetime earnings have been controlled for, the anomaly reported by Mitchell, Moore and Philips (1998) and Engen, Gale, and Uccello (1999) disappears. That is, high-income households in our data are more likely to be saving adequately for retirement. 
Model 3 adds in other indicators, which have plausible signs. The likelihood of being a high saver is low for smokers, perhaps because of a higher time preference rate for those households. The likelihood rises with declines in expected retirement age, with the extent to which the household has thought about retirement, and with the household's financial horizon. It is also higher for households who have contacted social security to find out about their benefits, and for households who have received a large inheritance.

\section{Effects of Social Security Reforms}

The Social Security program is of particular interest in analyzing the adequacy of household saving. Not only was the program instituted in response to widespread perceptions in financial fragility among the elderly, the program also provides the bulk of financial resources to most current, elderly households (Diamond and Orszag 2003).

The framework developed above can easily examine the impact of changes in social security benefits on the overall level of adequacy, and perhaps equally important, the effects on particular sub-groups. It can also compare these effects to those deriving from changes in other economic outcomes, like realizations of the stock market or health care costs. These items are examined in this section and the next.

Table 7 shows the effects of reducing Social Security benefits across-the-board by 15 percent or by 30 percent. Reducing benefits raises the optimal simulated wealth-earnings ratios, which exclude social security. As suspected, reductions in social security benefits have a significant impact on the share of households whose actual wealth-earnings ratios exceed the target ratios. A 30 percent reduction in benefits reduces the share of households above the median optimal ratio by 5 percentage points, or almost 10 percent of the total that exceed the 
median. The effect is felt fairly consistently across those households with and without pension coverage. Interestingly, there is essentially no effect on highly-educated households and a relatively large effect on less educated households, where the 5 percentage point drop represents a 12 percent decline in the share of households whose actual wealth-earnings ratios exceed the optimal ratios.

The change would hit moderate earnings households particularly hard. Households with lifetime earnings between $\$ 1.0$ and $\$ 1.5$ million would face a drop of 8 percentage points, more than 16 percent, in the share that exceed the optimal median wealth-earnings ratio. Likewise, households with current earnings between $\$ 20,000$ and $\$ 30,000$ would face a drop of 8 percentage points, or almost 20 percent.

\section{Sensitivity analysis}

For comparison purposes, the first line of table 8 repeats the base-case results from table 3. The following lines report the results of various sensitivity analyses. As noted above, a reduction of social security benefits by 30 percent reduces the proportion of households whose broad wealth exceeds the median target by 5 percentage points.

To simulate the effects of a substantial decline in the stock market, we reduce each household's actual wealth by 40 percent of its stock and mutual fund holdings and, on the assumption that retirement funds are divided equally between stocks and other assets, by 20 percent of balances in DC pensions, Individual Retirement Accounts, Keogh plans, and 401(k) plans. This has a very small impact on the results for the median household, presumably because stock holdings are concentrated among the wealthiest families. The effect is $20-40$ percent as large as reducing social security benefits. While this result might be thought to be attributable to 
the fact that the data are from 1992 and equity values and participation in the stock market have increased substantially since then, Engen, Gale, and Uccello (2004) show that even in more recent years variations in the stock market have little impact on the adequacy of wealth accumulation.

As a further sensitivity test, we raised all simulated wealth-earnings ratios by 20 percent. This scenario could cover a number of possibilities. For example, if health care accounts for 10 percent of household expenditure before retirement, this amounts to tripling health expenditure in retirement; if preretirement health expenditure is 20 percent of all household spending, it represents a doubling. Likewise, raising the simulated wealth-earnings ratios could be a rough way to proxy for uncertainty regarding health expenses or income in retirement. Although this may not be a worst-case scenario, a 20 percent increase does reduce the proportion of households who exceed the simulated median wealth-earnings ratios by only 7 percentage points. ${ }^{10}$

Some observers believe that the assumptions used in the social security trustees' forecasts and in this paper systematically understate the typical future life span. ${ }^{11}$ To account for this possibility, we raise survival rates by 10 percent. This increases life expectancy at birth by about 7.5 years for men and 8 years for women. The resulting survival rates are higher than those in the Social Security Administration's high-cost scenario. This change has a significant impact on the

\footnotetext{
${ }^{10}$ Fuchs (1998a) cites data showing that health expenditure per capita for persons over age sixty-five is more than three times greater than that before age sixty-five, but this includes government-provided care as well as out-ofpocket expense. Fuchs (1998b) notes that if health expenditures continue to grow at the same rate as they have in the past, health care for the elderly will absorb 10 percent of GDP in 2020, compared with 4.3 percent in 1995 . He estimates that this will require either a sizable increase in public health expenditure or a reduction in the amount of nonhealth private goods and services the elderly can purchase compared with earlier years, or both. See Hubbard, Skinner, and Zeldes (1994) for information on the age profile of health expenditure, and Dick, Garber, and MaCurdy (1994) for an analysis of nursing home stays.

${ }^{11}$ Lee and Skinner (1999).
} 
results, reducing the proportion of households that exceed the median saving benchmark by 10 percentage points in the HRS data.

Raising the predetermined retirement age to sixty-five raises the proportion of households who exceed the median wealth-earnings ratio by about 5 percentage points. $^{12}$

Equity in a business may reflect human capital that is specific to the owner. Households may be unable to cash in such wealth to finance retirement. Excluding all business wealth from the estimates reduces the share of households exceeding the median optimal wealth-earnings ratio by 4 percentage points.

\section{Comparisons with data on current earnings}

Comparisons of lifetime and current earnings are of interest both to provide information about income mobility and also to help resolve anomalous results in the literature, as discussed in the introduction.

Table 9 divides the sample into quartiles based on lifetime earnings and current earnings and measures the extent to which those with high lifetime earnings also have high current earnings. The table shows relatively strong correlation between current and lifetime earnings. About 55 percent of households are in the same quartile of the current earnings and lifetime earnings distributions, and another 36 percent are in adjacent quartiles. Less than 8 percent of households have a quartile ranking by one earnings measure that is two or three quartiles away from its quartile ranking with the other measure.

\footnotetext{
${ }^{12}$ To analyze retirement at age sixty-five, we raise the pension and social security replacement rates by 10 percent and allow earnings to continue between ages sixty-two and sixty-five according to the same age-earnings profile and the same stochastic process used in the rest of the analysis.
} 
The top panel of Table 10 shows the proportion of households in each current-earnings and lifetime-earnings quartile who have actual wealth-current earnings ratios that exceed their median optimal simulated ratios. (The wealth-current earnings ratios are taken from Engen, Gale, and Uccello 1999.) Almost three quarters of those in the top lifetime earnings quartile but the lowest current earnings quartile have actual wealth-current earning ratios above their median simulated ratio. In contrast, among those in the highest current earnings quartile but lowest lifetime earnings quartile, only 16 percent exceeded the median optimal simulated ratio of wealth to current earnings. These patterns are consistent with what would be expected if temporary fluctuations in earnings were substantial, but households were planning for retirement with respect to average lifetime earnings, rather than current earnings.

The bottom panel shows that among households with the same lifetime earnings, those with higher current earnings are much more likely to exceed the simulated optimal ratio of wealth to lifetime earnings. This suggests that transitory income components are substantial, and that such components are typically saved.

Table 11 shows that the classification of households as above or below the median simulated optimal wealth-earnings ratio does not depend too much on whether current or lifetime earnings are used as the denominator. Among the 56 percent of households whose wealth-tolifetime earnings exceed the median optimal simulated ratios, about $7 / 8$ also exceed the median target based on current earnings. Likewise, of the 51 percent of households who exceed the median optimal wealth-current earnings ratios given their characteristics, about 95 percent exceed the analogous wealth-lifetime earnings ratio. This is not an indication that use of lifetime earnings is unimportant -- as shown above, controlling for lifetime earnings affects the classification of which households are undersaving. Rather, it is mainly a reflection of the fact 
that current age-adjusted earnings and average, age-adjusted lifetime earnings tend to be relatively close to each other for most households in a given year.

\section{Concluding comments}

This paper builds on our previous work incorporating uncertainty into analysis of the adequacy of saving by incorporating measures of lifetime earnings into the analysis as well. The focus on uncertainty is crucial because it fundamentally alters the interpretation of observed results. The addition of information on lifetime earnings is valuable because theory and evidence indicate that average lifetime earnings more closely approximates the standard of living the household is trying to obtain in retirement than does current earnings, which tend to fluctuate.

An important caveat to our results is that we compare the distributions of observed and simulated wealth outcomes, but can not derive optimal wealth values for individual households. In an important recent paper, Scholz, Seshadri, and Khitatrakun (2003) are able to solve for optimal wealth accumulation for each household, using a model that recognizes uncertainty relating to earnings, mortality and health expenditures. In all important respects, their results are similar to those reported here and in Engen, Gale, and Uccello (1999). In particular, they find that most households are saving at least as much as the underlying simulation model indicates is optimal, and that there is undersaving among the 20 percent of households at the low-end of the wealth distribution. This suggests that incorporating household-specific targets strengthens the support for the conclusions obtained above. 


\section{References}

Banks, James, Richard Blundell, and Sarah Tanner. 1998. "Is There a Retirement-Savings Puzzle?" American Economic Review 88(4): 769-88.

Bernheim, B. Douglas. 1992. "Is the Baby Boom Generation Preparing Adequately for Retirement? Technical Report." Unpublished paper. New York: Merrill Lynch (September).

Bernheim, B. Douglas, and John Karl Scholz. 1993. "Private Saving and Public Policy." In Tax Policy and the Economy, vol. 7, edited by James Poterba. Cambridge and London: MIT Press.

Carroll, Christopher D. 1992. "The Buffer-Stock Theory of Saving: Some Macroeconomic Evidence.” Brookings Papers on Economic Activity, 2: 1992, 61-135.

Carroll, Christopher D. 2000. "Why Do the Rich Save So Much?" in Joel P. Slemrod, ed. Does Atlas Shrug? The Economic Consequences of Taxing the Rich. Forthcoming.

Congressional Budget Office. 2003. "Baby Boomers' Retirement Prospects: An Overview." November.

Diamond, Peter and Peter Orszag. 2003. Saving Social Security. Washington, DC: Brookings Institution Press.

Dick, Andrew, Alan M. Garber, and Thomas E. MaCurdy. 1994. "Forecasting Nursing Home Utilization of Elderly Americans." In Studies in the Economics of Aging, edited by David A. Wise. Chicago and London: University of Chicago Press.

Dynan, Karen E., Jonathan Skinner, and Stephen P. Zeldes. 2000. "Do the Rich Save More?" NBER working paper 7906. September.

Dynan, Karen E., Jonathan Skinner, and Stephen P. Zeldes. 2002. "The Importance of Bequests and Life Cycle Saving in Capital Accumulation: A New View," American Economic Review, May.

Engen, Eric M.1993a. "Consumption, Uncertain Lifespan, and Euler Equations: Estimation with Panel Data." Unpublished paper. University of California, Los Angeles.

Engen, Eric M.. 1993b. "Consumption and Saving in a Life-Cycle Model with Stochastic Earnings and Uncertain Lifespan.” Unpublished paper. Washington: Federal Reserve Board (October).

Engen, Eric M., William G. Gale, and Cori E. Uccello. 1999. "The Adequacy of Household Saving." Brookings Papers on Economic Activity. No 2, pp. 65-187. 
Engen, Eric M., William G. Gale, and Cori E. Uccello. 2004 "Effects of Stock Market Fluctuations on the Adequacy of Households' Retirement Saving" mimeo. Brookings.

Fuchs, Victor R. 1998a. "Provide, Provide: The Economics of Aging." NBER Working Paper 6642. Cambridge, Mass.: National Bureau of Economic Research (July).

Fuchs, Victor R.. 1998b. "Health Care for the Elderly: How Much? Who Will Pay for It?" NBER Working Paper 6755. Cambridge, Mass.: National Bureau of Economic Research (October).

Gale, William. 1997. "Will the Baby Boom Be Ready for Retirement?” Brookings Review 15(3): 4-9 (Summer).

Gentry, William M., and R. Glenn Hubbard. 1998. "Why do the Wealthy Save so Much? Saving and Investment Decisions of Entrepreneurs." Working Paper (July).

Gustman, Alan L., and Thomas L. Steinmeier. 1998. "Effects of Pensions on Saving: Analysis with Data from the Health and Retirement Survey." NBER Working Paper 6681. Cambridge, Mass.: National Bureau of Economic Research (August).

Hubbard, Glen R., Jonathan Skinner, and Stephen P. Zeldes. 1994. "The Importance of Precautionary Motives in Explaining Individual and Aggregate Saving." Carnegie-Rochester Conference Series on Public Policy 40(0): 59-125 (June).

Hubbard, R. Glenn, Jonathan Skinner, and Stephan P. Zeldes. 1995. "Precautionary Saving and Social Insurance." Journal of Political Economy 103: 360-399.

Khitatrakun, Surachai, Yuichi Kitamura and John Karl Scholz. 2000. "Pensions and Wealth: New Evidence from the Health and Retirement Study." University of Wisconsin.

Kotlikoff, Laurence J., Avia Spivak, and Lawrence H. Summers. 1982. "The Adequacy of Savings." American Economic Review 72(5): 1056-69 (December).

Lee, Ronald, and Jonathan Skinner. 1999. "Will Aging Baby Boomers Bust the Federal Budget?” Journal of Economic Perspectives 13(1): 117-40 (Winter).

Mitchell, Olivia, James Moore, and John Phillips. 1998. "Explaining Retirement Saving Shortfalls.” Pension Research Council, Philadelphia, PA.

Moore, James F., and Olivia S. Mitchell. 1997. "Projected Retirement Wealth and Savings Adequacy in the Health and Retirement Survey." NBER Working Paper 6240. Cambridge, Mass.: National Bureau of Economic Research (October).

Robb, A. L., and J. B. Burbidge. 1989. “Consumption, Income, and Retirement.” Canadian Journal of Economics 22(3): 522-42 (August). 
Scholz, John Karl, Ananth Seshadri and Surachai Khitatrakun. 2003. "Are Americans Saving 'Optimally' for Retirement?' University of Wisconsin.

U.S. Social Security Administration. 1997. "Social Security Area Population Projections." Actuarial Study 112. Baltimore: Social Security Administration, Office of the Chief Actuary.

Warshawsky, Mark J., and John Ameriks. 1998. "What Does Financial Planning Software Say About Americans' Preparedness for Retirement?” TIAA-CREF Institute, New York, NY (July). 
Table 1

Median Simulated Optimal Wealth-to-Lifetime Earnings Ratios ${ }^{1}$ by Age, Education, and Pension Status

\begin{tabular}{|c|c|c|c|c|}
\hline \multirow{2}{*}{ Age } & \multicolumn{2}{|c|}{ Less than 4 years of College } & \multicolumn{2}{|c|}{ At least 4 years of College } \\
\hline & No Pension & Pension & No Pension & Pension \\
\hline $30-34$ & 0.0234 & 0.0211 & 0.0069 & 0.0066 \\
\hline $35-39$ & 0.0363 & 0.0295 & 0.0153 & 0.0109 \\
\hline $40-44$ & 0.0520 & 0.0391 & 0.0379 & 0.0210 \\
\hline $45-49$ & 0.0671 & 0.0492 & 0.0656 & 0.0363 \\
\hline $50-54$ & 0.0739 & 0.0530 & 0.0847 & 0.0489 \\
\hline $55-59$ & 0.0752 & 0.0525 & 0.0945 & 0.0555 \\
\hline $60-62$ & 0.0717 & 0.0492 & 0.0964 & 0.0553 \\
\hline
\end{tabular}

Source: Authors' calculations.

(1) Lifetime earnings is defined as the present value of all earnings received to date. Time preference rate $=.03$ 
Table 2

Distribution of Simulated Optimal Wealth-Lifetime Earnings Ratios ${ }^{1}$

\begin{tabular}{lccccc}
\hline \hline \multirow{2}{*}{ Age } & 5th Percentile & 25th Percentile & Median & 75th Percentile & 95th Percentile \\
\cline { 5 - 6 } $30-34$ & 0.0000 & 0.0024 & 0.0066 & 0.0188 & 0.0543 \\
$35-39$ & 0.0004 & 0.0030 & 0.0109 & 0.0306 & 0.0765 \\
$40-44$ & 0.0006 & 0.0057 & 0.0210 & 0.0483 & 0.1005 \\
$45-49$ & 0.0012 & 0.0135 & 0.0363 & 0.0683 & 0.1181 \\
$50-54$ & 0.0031 & 0.0232 & 0.0489 & 0.0792 & 0.1233 \\
$55-59$ & 0.0060 & 0.0300 & 0.0555 & 0.0818 & 0.1198 \\
$60-62$ & 0.0067 & 0.0322 & 0.0553 & 0.0791 & 0.1119 \\
\hline
\end{tabular}

Source: Authors' calculations.

(1) Lifetime earnings is defined as the present value of all earnings received to date. Time preference rate $=.03$ 
Table 3

Percentage of Households with Wealth-Lifetime Earnings Ratios At or Above Simulated Mediana

\begin{tabular}{|c|c|c|c|}
\hline & $\begin{array}{l}\text { Narrow } \\
\text { Wealth }^{\text {b }} \\
\end{array}$ & $\begin{array}{c}\text { Intermediate } \\
\text { Wealth }^{\mathrm{c}}\end{array}$ & $\begin{array}{c}\text { Broad } \\
\text { Wealth }^{\mathrm{d}} \\
\end{array}$ \\
\hline Full Sample & 47 & 56 & 65 \\
\hline \multicolumn{4}{|l|}{ Either spouse has DB pension coverage } \\
\hline All & 51 & 61 & 71 \\
\hline Husband with 4 or more years of college & 65 & 72 & 77 \\
\hline Husband with less than 4 years of college & 46 & 57 & 68 \\
\hline \multicolumn{4}{|l|}{ Neither spouse has DB pension coverage } \\
\hline All & 35 & 42 & 51 \\
\hline Husband with 4 or more years of college & 46 & 53 & 62 \\
\hline Husband with less than 4 years of college & 31 & 39 & 48 \\
\hline Husband with 4 or more years of college & 61 & 68 & 74 \\
\hline Husband with less than 4 years of college & 42 & 52 & 62 \\
\hline \multicolumn{4}{|l|}{ Age } \\
\hline $51-54$ & 44 & 54 & 64 \\
\hline $55-59$ & 49 & 58 & 66 \\
\hline $60-61$ & 47 & 56 & 65 \\
\hline \multicolumn{4}{|l|}{ Current Earnings (in $\$ 000$ 's) } \\
\hline $0-10$ & 19 & 34 & 53 \\
\hline $10-20$ & 28 & 40 & 51 \\
\hline $20-30$ & 31 & 42 & 51 \\
\hline $30-40$ & 36 & 45 & 57 \\
\hline $40-50$ & 43 & 56 & 66 \\
\hline $50-75$ & 57 & 64 & 72 \\
\hline $75+$ & 66 & 73 & 79 \\
\hline \multicolumn{4}{|l|}{ Lifetime Earnings (in \$millions) } \\
\hline $0-1.0$ & 27 & 39 & 49 \\
\hline $1-1.5$ & 33 & 47 & 60 \\
\hline $2.5-2.0$ & 50 & 57 & 66 \\
\hline $2.0-2.5$ & 55 & 65 & 72 \\
\hline $2.5+$ & 60 & 66 & 72 \\
\hline \multicolumn{4}{|l|}{ Current Earnings Quartile } \\
\hline First & 29 & 40 & 50 \\
\hline Second & 40 & 51 & 62 \\
\hline Third & 53 & 61 & 70 \\
\hline Fourth & 65 & 71 & 78 \\
\hline \multicolumn{4}{|l|}{ Lifetime Earnings Quartile } \\
\hline First & 29 & 40 & 53 \\
\hline Second & 45 & 55 & 65 \\
\hline Third & 54 & 63 & 71 \\
\hline Fourth & 59 & 66 & 72 \\
\hline
\end{tabular}

Source: Authors' calculations using the 1992 HRS.

a. Simulated medians assume a time preference rate of 3 percent.

b. Broad wealth less all equity in the primary residence.

c. Broad wealth less half of all equity in the primary residence.

d. The sum of equity in the primary residence, other real estate equity, equity in businesses, and net financial assets. 
Table 4

Distribution of Simulated and Actual Wealth-Earnings Ratios

\begin{tabular}{|c|c|c|c|c|c|}
\hline & 5 th & 25 th & Median & 75 th & 95 th \\
\hline \multicolumn{6}{|c|}{ Simulated Wealth-Lifetime Earnings Ratios, by Lifetime Earnings Quartile ${ }^{\mathrm{a}}$} \\
\hline All & 0.0728 & 0.0739 & 0.0750 & 0.0815 & 0.0961 \\
\hline Lowest & 0.0728 & 0.0739 & 0.0750 & 0.0754 & 0.0920 \\
\hline Second & 0.0728 & 0.0739 & 0.0750 & 0.0754 & 0.0935 \\
\hline Third & 0.0728 & 0.0739 & 0.0750 & 0.0815 & 0.0957 \\
\hline Highest & 0.0728 & 0.0747 & 0.0755 & 0.0935 & 0.0964 \\
\hline \multicolumn{6}{|c|}{ Actual Wealth-Lifetime Earnings Ratios, by Lifetime Earnings Quartile ${ }^{\mathrm{b}}$} \\
\hline All & 0.0031 & 0.0430 & 0.0906 & 0.1768 & 0.4740 \\
\hline Lowest & -0.0026 & 0.0165 & 0.0554 & 0.1322 & 0.4974 \\
\hline Second & 0.0066 & 0.0398 & 0.0860 & 0.1664 & 0.4867 \\
\hline Third & 0.0169 & 0.0590 & 0.1024 & 0.1726 & 0.3924 \\
\hline Highest & 0.0122 & 0.0593 & 0.1248 & 0.2211 & 0.4776 \\
\hline
\end{tabular}

Source: Authors' calculations.

a. Simulated medians assume a time preference rate of 3 percent.

b. Actual wealth-earnings ratios reflect the intermediate wealth measure--the sum of half of the equity in the primary residence, other real estate equity, equity in businesses, and net financial assets. 
Table 5

\section{Characteristics of High and Low Savers ${ }^{\mathrm{a}}$}

Percent of all respondents except where stated otherwise

Broad wealth (dollars)

Combined current wages of husband and wife (dollars) ${ }^{b}$

Combined lifetime wages of husband and wife (dollars)

Age of husband (years)

Number of children living at home

$\begin{array}{rr}56 & 56 \\ 0.86 & 0.79\end{array}$

Husband has 4 of more years of college

Either spouse has DB pension coverage

Either spouse is self-employed

Husband is nonwhite

Husband is Hispanic

Husband is in fair or poor health

Wife is in fair or poor health

Husband smokes

Wife smokes

$\begin{array}{rr}64 & 79 \\ 21 & 27 \\ 13 & \\ 8 & \\ 12 & \\ 16 & 10 \\ 31 & 18 \\ 28 & 18 \\ -0.03 & 0.03 \\ 1 & \\ 7 & -0.06 \\ -0.11 & \end{array}$

selative mortality optimism (age $75^{\circ}$

Husband's mortality optimism index missing

Husband certain he will not attain age 75

Wife's relative mortality optimism (age $75^{\mathrm{c}}$

Wife's mortality optimism index missing

Wife certain she will not attain age 75

Expected retirement age (years)

Expect never to retire

Don't know when will retire

Thought about retirement

$$
\text { Hardly at all }
$$

Little

Some

A lot

Not ascertained

Financial planning horizon

$0-1$ year
$1-5$ years
$5-10$ years
$10+$ years
Not ascertained

Risk aversion

Level 1 (least risk averse)

Level 2

Level 3

Level 4 (most risk averse)

Received inheritance

a. A high saver is defined as a household whose intermediate wealth-lifetime earnings ratio exceeds the median simulated optimal ratio for households with the same characteristics, when the simulation model uses a time preference rate of 3 percent.

b. Values are medians for households with the stated characteristic; values for other characteristics are means.

c. The mortality optimism index is the difference between the respondent's subjective expectation of life expectancy and an objective measure of that respondent's life expectancy, as a perentage of the latter. 
Table 6

Probit Regression Results Using Wealth-Lifetime Earnings Ratios

\begin{tabular}{|c|c|c|c|c|c|c|}
\hline & \multicolumn{2}{|c|}{ Model 1} & \multicolumn{2}{|c|}{ Model 2} & \multicolumn{2}{|c|}{ Model 3} \\
\hline & $\begin{array}{l}\text { Coefficient } \\
\text { Estimate }\end{array}$ & $\begin{array}{l}\text { Marginal } \\
\text { Probability }\end{array}$ & $\begin{array}{l}\text { Coefficient } \\
\text { Estimate }\end{array}$ & $\begin{array}{l}\text { Marginal } \\
\text { Probability }\end{array}$ & $\begin{array}{l}\text { Coefficient } \\
\text { Estimate }\end{array}$ & $\begin{array}{l}\text { Marginal } \\
\text { Probability }\end{array}$ \\
\hline \multicolumn{7}{|l|}{ Age } \\
\hline $55-59$ & 0.074 & 0.029 & $0.132 * *$ & 0.052 & $0.170 * * *$ & 0.067 \\
\hline $60-61$ & 0.106 & 0.042 & $0.201 * *$ & 0.079 & $0.266 * * *$ & 0.104 \\
\hline \multicolumn{7}{|l|}{ Household current earnings (in 000's) } \\
\hline $20-30$ & & & -0.143 & -0.057 & -0.172 & -0.068 \\
\hline $30-40$ & & & -0.178 & -0.071 & $-0.266 * *$ & -0.106 \\
\hline $40-50$ & & & 0.012 & 0.005 & -0.035 & -0.014 \\
\hline $50-75$ & & & $0.267 * *$ & 0.105 & $0.235 *$ & 0.092 \\
\hline $75+$ & & & $0.486 * * *$ & 0.186 & $0.505 * * *$ & 0.192 \\
\hline \multicolumn{7}{|l|}{ Household lifetime earnings (in millions) } \\
\hline $1.0-1.5$ & 0.104 & 0.041 & 0.096 & 0.038 & 0.045 & 0.018 \\
\hline $1.5-2.0$ & $0.320 * * *$ & 0.125 & $0.202 *$ & 0.079 & 0.107 & 0.042 \\
\hline $2.0-2.5$ & $0.417 * * *$ & 0.161 & 0.149 & 0.059 & -0.057 & -0.023 \\
\hline $2.5+$ & $0.405 * * *$ & 0.157 & 0.011 & 0.004 & -0.209 & -0.083 \\
\hline \multicolumn{7}{|l|}{ Children living at home } \\
\hline 1 & -0.038 & -0.015 & -0.056 & -0.022 & -0.042 & -0.017 \\
\hline 2 & -0.020 & -0.008 & -0.059 & -0.024 & -0.012 & -0.005 \\
\hline$>=3$ & -0.116 & -0.046 & -0.142 & -0.057 & -0.061 & -0.024 \\
\hline Husband has college degree & $0.261 * * *$ & 0.102 & $0.179 * * *$ & 0.071 & 0.071 & 0.028 \\
\hline Either spouse is self-employed & $0.469 * * *$ & 0.181 & $0.454 * * *$ & 0.175 & $0.537 * * *$ & 0.205 \\
\hline Either spouse has pension coverage & $0.584 * * *$ & 0.230 & $0.579 * * *$ & 0.228 & $0.510 * * *$ & 0.201 \\
\hline Husband is nonwhite & $-0.340 * * *$ & -0.135 & $-0.348 * * *$ & -0.138 & $-0.329 * * *$ & -0.131 \\
\hline Husband is Hispanic & -0.107 & -0.042 & -0.098 & -0.039 & -0.074 & -0.029 \\
\hline Husband is in fair or poor health & & & & & -0.023 & -0.009 \\
\hline Wife is in fair or poor health & & & & & -0.042 & -0.017 \\
\hline Husband smokes & & & & & $-0.209 * * *$ & -0.083 \\
\hline Wife smokes & & & & & $-0.293 * * *$ & -0.117 \\
\hline Husband's relative mortality optimism (age 75) & & & & & 0.038 & 0.015 \\
\hline Husband's relative mortality optimism missing & & & & & 0.291 & 0.112 \\
\hline Husband certain he will not attain age 75 & & & & & $-0.283 *$ & -0.113 \\
\hline Wife's relative mortality optimism (age 75) & & & & & 0.089 & 0.035 \\
\hline Wife's relative mortality optimism missing & & & & & 0.036 & 0.014 \\
\hline Wife is certain she will not attain age 75 & & & & & 0.078 & 0.031 \\
\hline \multicolumn{7}{|l|}{ Expected retirement age } \\
\hline $56-59$ & & & & & $-0.504 * *$ & -0.198 \\
\hline $60-61$ & & & & & $-0.452 *$ & -0.178 \\
\hline 62 & & & & & $-0.934 * * *$ & -0.354 \\
\hline $63-64$ & & & & & $-1.065 * * *$ & -0.390 \\
\hline 65 & & & & & $-1.335 * * *$ & -0.473 \\
\hline $66-69$ & & & & & $-1.307 * * *$ & -0.457 \\
\hline 70 & & & & & $-1.420 * * *$ & -0.515 \\
\hline Will never retire & & & & & 0.608 & 0.226 \\
\hline Don't kow when will retire & & & & & $0.313 * *$ & 0.121 \\
\hline \multicolumn{7}{|l|}{ Thought about retirement } \\
\hline A little & & & & & 0.056 & 0.022 \\
\hline Some & & & & & $0.243 * * *$ & 0.095 \\
\hline A lot & & & & & $0.202 * *$ & 0.079 \\
\hline Not ascertained & & & & & -0.262 & -0.104 \\
\hline
\end{tabular}




\begin{tabular}{|c|c|c|c|c|}
\hline \multicolumn{5}{|l|}{ Financial planning horizon } \\
\hline $1-5$ years & & & $0.306 * * *$ & 0.120 \\
\hline $5-10$ years & & & $0.222 * *$ & 0.087 \\
\hline $10+$ years & & & $0.309 * *$ & 0.119 \\
\hline Not ascertained & & & 0.165 & 0.064 \\
\hline \multicolumn{5}{|l|}{ Risk aversion } \\
\hline Level 2 & & & 0.049 & 0.019 \\
\hline Level 3 & & & 0.151 & 0.059 \\
\hline Level 4 (most averse) & & & $0.155 *$ & 0.061 \\
\hline Ever contacted Social Security & & & $0.146 * *$ & 0.058 \\
\hline \multicolumn{5}{|l|}{ Inheritance (in 000's) } \\
\hline $0-5$ & & & $-0.334 * *$ & -0.132 \\
\hline $5-10$ & & & 0.068 & 0.027 \\
\hline $10-25$ & & & 0.049 & 0.019 \\
\hline $25-100$ & & & $0.399 * * *$ & 0.151 \\
\hline $100+$ & & & $0.874 * * *$ & 0.295 \\
\hline Constant & $-0.654 * * *$ & $-0.717 * * *$ & 0.137 & \\
\hline
\end{tabular}

$* * * \mathrm{p}<.01 ; * * \mathrm{p}<.05 ; * \mathrm{p}<.10$

$\mathrm{N}=2476$

a. The dependent variable takes a value of one if the household's actual intermediate wealth-lifetime earnings ratio exceeds the simulated wealthearnings ratio, and zero otherwise. 
Table 7

Effects of Social Security Benefit Cuts on the Adequacy of Saving (Using Wealth-Lifetime Earnings)

\begin{tabular}{|c|c|c|c|}
\hline & Base Case & 15 Percent Cut & 30 Percent Cut \\
\hline Full Sample & 56 & 54 & 51 \\
\hline \multicolumn{4}{|l|}{ Either spouse has DB pension coverage } \\
\hline All & 61 & 59 & 56 \\
\hline Husband with 4 or more years of college & 72 & 70 & 68 \\
\hline Husband with less than 4 years of college & 57 & 54 & 51 \\
\hline \multicolumn{4}{|l|}{ Neither spouse has DB pension coverage } \\
\hline All & 42 & 40 & 38 \\
\hline Husband with 4 or more years of college & 53 & 53 & 53 \\
\hline Husband with less than 4 years of college & 39 & 36 & 34 \\
\hline Husband with 4 or more years of college & 68 & 66 & 65 \\
\hline Husband with less than 4 years of college & 52 & 49 & 46 \\
\hline \multicolumn{4}{|l|}{ Age } \\
\hline $51-54$ & 54 & 52 & 49 \\
\hline $55-59$ & 58 & 55 & 52 \\
\hline $60-61$ & 56 & 54 & 52 \\
\hline \multicolumn{4}{|l|}{ Current Earnings (in $\$ 000$ 's) } \\
\hline $0-10$ & 34 & 31 & 28 \\
\hline $10-20$ & 40 & 39 & 35 \\
\hline $20-30$ & 42 & 39 & 34 \\
\hline $30-40$ & 45 & 42 & 40 \\
\hline $40-50$ & 56 & 52 & 50 \\
\hline $50-75$ & 64 & 62 & 59 \\
\hline $75+$ & 73 & 71 & 69 \\
\hline \multicolumn{4}{|l|}{ Lifetime Earnings (in \$millions) } \\
\hline $0-1.0$ & 39 & 37 & 37 \\
\hline $1-1.5$ & 47 & 44 & 39 \\
\hline $2.5-2.0$ & 57 & 55 & 53 \\
\hline $2.0-2.5$ & 65 & 61 & 58 \\
\hline $2.5+$ & 66 & 64 & 62 \\
\hline
\end{tabular}


Table 8

Sensitivity Analysis : Shares of Households with Wealth-Lifetime Earnings Ratios at or above the Simulated Median Wealth-Lifetime Earnings Ratio Under Alternative Scenarios

\begin{tabular}{lccc}
\hline \hline \multicolumn{1}{c}{ Case } & Intermediate Wealth & & Broad Wealth \\
Base Case $^{\mathrm{a}}$ & 56 & 65 \\
30 percent cut in social security benefits & 51 & 60 \\
40 percent decline in stock market & 54 & 64 \\
$\begin{array}{l}\text { 20 percent increase in all simulated } \\
\text { wealth-earnings ratios }\end{array}$ & 49 & 58 \\
10 percent increase in survival rates & 46 & 55 \\
Retire at age 65 & 61 & 69 \\
Exclude Business Wealth & 52 & 61 \\
\hline
\end{tabular}

Source: Authors' calculations.

a. The parameters of the base case are as follows: time preference rate $=.03$, intertemporal elasticity of substitution $($ IES $)=.33$ autoregressive persistence parameter $=.85$, retirement at age sixty-two, a real after-tax rate of return of 3 percent, and social security and pension income derived from the average final earnings of one's own education class.

b. Specifications of the sensitivity analysis are described in the text. Wealth measures are as defined in the text. 
Table 9

Allocation of Households,

by Current and Lifetime Earnings

Lifetime Earnings Quartile

\begin{tabular}{lrrrr}
\hline \hline & Lowest & Second & Third & Highest \\
\hline Current Earnings Quartile & & & & \\
$\quad$ Lowest & 17.0 & 5.1 & 1.9 & 0.9 \\
Second & 6.5 & 10.8 & 6.0 & 1.6 \\
Third & 1.1 & 7.7 & 10.7 & 5.5 \\
Highest & 0.4 & 1.4 & 6.4 & 17.0 \\
& & & & \\
\hline
\end{tabular}

Source: Authors' calculations using the 1992 HRS. 
Table 10

Percentage of Households At or Above Median Simulated Wealth-Current

Earnings Ratio ${ }^{a}$ Using Intermediate Wealth Measure ${ }^{b}$

by Current and Lifetime Earnings

Lifetime Earnings Quartile

\begin{tabular}{ccccc}
\hline \hline & Lowest & Second & Third & Highest \\
\hline & Using Wealth-Current Earnings & & \\
Current Earnings Quartile & & & & \\
Lowest & 37 & 50 & 51 & 61 \\
Second & 29 & 50 & 55 & 73 \\
Third & 23 & 42 & 58 & 64 \\
Highest & 16 & 56 & 61 & \\
& Using Wealth-Lifetime Earnings & & 28 \\
Current Earnings Quartile & & & & 40 \\
Lowest & 40 & 44 & 34 & 71 \\
Second & 41 & 58 & 54 & 69 \\
Third & 36 & 55 & 64 & 77 \\
Highest & 49 & 79 & & \\
\end{tabular}

Source: Authors' calculations using the 1992 HRS.

a. Simulated medians assume a time preference rate of 3 percent.

b. Intermediate wealth is the sum of half of the equity in the primary residence, other real estate equity, equity in businesses and net financial assets. 
Table 11

Allocation of Households

By Whether At or Above Wealth to Current and Lifetime Earnings

Simulated Medians

\begin{tabular}{lccc}
\hline \hline & \multicolumn{3}{c}{ At or Above Wealth-Lifetime Earnings Median } \\
At or Above Wealth- & No & All \\
\cline { 2 - 4 } Current Earnings Median & Yes & 3 & 51 \\
\hline \multirow{2}{*}{ Yes } & 48 & 41 & 49 \\
No & 8 & & 100 \\
All & 56 & 44 & \\
\hline
\end{tabular}

Source: Authors' calculations using the 1992 HRS. 


\section{RECENT WORKING PAPERS FROM THE \\ Center For Retirement Research at Boston College}

Living Arrangements and Supplemental Security Income Receipt Among the Aged Melissa M. Favreault and Douglas A. Wolf, February 2004

Interactions Between Social Security Reform and the Supplemental Security Income Program for the Aged

Paul S. Davies and Melissa M. Favreault, February 2004

Supply-Side Consequences of Social Security Reform: Impacts on Saving and Employment

Barry Bosworth and Gary Burtless, January 2004

It's All Relative: Understanding the Retirement Prospects of Baby-Boomers

Barbara A. Butrica, Howard M. Iams, and Karen E. Smith, November 2003

The Notional Defined Contribution Model: An Assessment of the Strengths and Limitations of a New Approach to the Provision of Old Age Security

John B. Williamson and Matthew Williams, October 2003

Simulating the Distributional Consequences of Personal Accounts: Sensitivity to Annuitization Options

Cori E. Uccello, Melissa M. Favreault, Karen E. Smith, and Lawrence H. Thompson, October 2003

Aggregate Implications of Defined Benefit and Defined Contribution Systems Francisco Gomes and Alexander Michaelides, September 2003

Can Unexpected Retirement Explain the Retirement-Consumption Puzzle? Evidence for Subjective Retirement Explanations Melvin Stephens Jr. and Steven J. Haider, August 2003

Employment, Social Security and Future Retirement Outcomes for Single Mothers Richard W. Johnson, Melissa M. Favreault, and Joshua H. Goldwyn, July 2003

The Outlook for Pension Contributions and Profits in the U.S. Alicia H. Munnell and Mauricio Soto, June 2003

Social Security Reform and the Exchange of Bequests for Elder Care Meta Brown, June 2003

All working papers are available on the Center for Retirement Research website (http://www.bc.edu/crr) and can be requested by e-mail (crr@bc.edu) or phone (617-552-1762). 